\title{
The Predicating determinants accessibility of credit small and medium enterprise in the construction industry in South Africa.
}

\author{
Olanrewaju Abdul Balogun ${ }^{\mathrm{a}}$, Justus Agumba, and Nazeem Ansary ${ }^{\mathrm{a}, \mathrm{b}, *}$ \\ ${ }^{1}$ Department of Construction Management and Quantity Surverying, University of Johannesburg.lbalogun@uj.ac.za

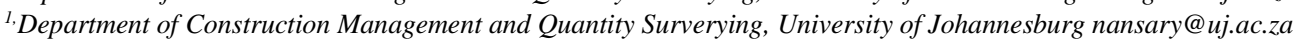 \\ ${ }^{3}$ Department of Construction Management and Quantity Surverying, University of Duban \\ JustusA@dut.ac.za
}

\begin{abstract}
This paper focuses on determining the demographic and company profile that predict credit accessibility for small and medium construction enterprises (CSMEs) from banks in South Africa.The significance of CSMEs in the economy has been recognised. However, construction SMEs in many countries, in particular developing countries, are not performing well. One of the factors for poor performance is lack of credit accessibility to fund SMEs operations and expansion. Even those who get access to credit do not get adequate credit they applied for. A quantitative philosophy of research was adopted which is positivism approach. Hence, data was collected using, questionnaire survey from 179 CSMEs who were conveniently sampled. The questionnaire was developed from extant literature review. The demographic and company profile determinants predicting credit accessibility were identified and modelled with full credit accessibility and credit accessibility to the SMEs irrespective of the amount obtained. The data was analysed using statistical package for the social sciences (SPSS) version 22. Binary logistic regression analysis was used to analyse the predictors of credit from the banks. The results revealed that the credit accessed irrespective of the amount and those who did not receive credit when modelled with the predictors suggested not significant predictors. However, when the predicators were modelled with full and partial credit the results established that, age group, current position in the organization, tax number and location were good predicators of partial credit. The gender of the respondent, type of business ownership and collateral (security) did not predict full credit being obtained.The study cannot be generalised across South Africa because the study was only conducted in the Gauteng province. The value of this study informs CSMEs owners and managers in the construction industry to provide, their age, current position in the organization when applying for credit. Furthermore, they should provide the tax number and the location of the business in order for them to improve their chances of obtain full credit from banks.
\end{abstract}

Keywords: credit accessibility, determinants of credit accessibility, full credit, small and medium enterprises ;

\section{Introduction}

The term Small and Medium Enterprises (SME) covers a wide range of definitions which, varies from country to country. Some of the commonly used criteria are the number of employees, total net assets, sales and investment level. However, the most common characteristics in the definition is number of permanent employees. [1] defined SMEs as companies that have up to 300 employees and total assets and sales of up to $\$ 15$ Million. However, in the South African context in the construction industry, small enterprise is defined as having less than 50 employees, having an annual turnover of less than R5million, while medium enterprises have between 51 and 200 employees and less than R20million turnover. It can therefore be justified that SMEs are defined differently from country to country (National

Corresponding author: lbalogun@uj.ac.za/balogununlimited@gmail.com 
Business Act, 2003). Despite the variance in definition SMEs contribute immensely to the economic gains in most countries including South Africa

Despite its importance to the economy in South Africa, small and medium construction enterprises (SME) sector is described as largely underdeveloped and lacking the managerial and technical skills and sophistication enjoyed by larger well established contractors. The SMEs are left on the periphery of the mainstream economy and do not participate fully in the economy [8]. [15] opined that lack of knowledge including knowledge of pricing procedures, contractual rights and obligations; law, management techniques and principles as well as technology were a challenge to SMEs.

It can further be stated that contractors registered in the lower grades of the Construction Industry Development Board (CIDB) [7] and [8] contractor register are small and medium. Hence, they are more likely to have limited formal education, which is based on a construction craft or trade training such as carpentry, plumbing, electrical installation and bricklaying. This training is probably in the form of learnership [7] and [3]. Furthermore, past studies in South Africa had revealed constraints and challenges of capacity and financial resources among SMEs [9]; [2]. [12] they inferred that SMEs are not able to access finance or credit hence it stifles their growth and capability.

It is accepted that SMEs are a vehicle of economic empowerment in the construction industry and other industries in South Africa. However, they are phased with numerous constraints to enable them maximize their economic potential. Furthermore, construction SMEs find it difficult to access the credit they applied for. It can be unequivocally indicated that there is lack of studies to determine the determinants predicting full credit and partial credit accessibility and also assessing whether the construction SMEs accessed the credit or not. Lack of consensus on the predicators of credit accessibility among SMEs is a problem that requires to be solved. The main aim of the study was to investigate credit accessibility among construction SMEs. This study is therefore guided by three specific research questions: viz;

- What factors prevent construction SMEs from accessing credit?

- What are the socio-economic and demographic predicators of full credit accessibility from financial institutions?

- What are the socio-economic and demographic predicators of credit accessibility from financial institutions?

Therefore the objectives of the study to answer the specific research questions were:

- $\quad$ To determine the factors that prevent construction SMEs from accessing credit;

- To assess the socio-economic and demographic determinants predicting full credit accessibility from financial institutions; and

- To evaluate the socio-economic and demographic determinants predicting credit accessibility from financial institutions.

\subsection{Literature Review predictors to access to funds (CSMEs)}

\subsection{Selected Determinants of credit accessibility for small and medium enterprise}

This section discusses the determinants of credit accessibility as per the reviewed literature;

\subsubsection{Gender}

According to [18] suggested that gender play a significant role to access credit. A number of studies have shown that female SMEs are more constrained than their male counterparts in SMEs in accessing credit.[4]and [5] in his study suggested that female SMEs face more obstacles while accessing credit compared to male counterparts.[15] analysed gender differences in accessing credit and explained that female are more financial constrained compared to their male counterparts in accessing credit.[5] and [2] indicated that access to credit is more oriented towards male than female.[8] in their study of SMEs with regards to the impact of gender on access to credit, established that female get credit easier compared to their male counterparts. It can therefore be argued that gender predicts credit accessibility.

\subsubsection{Age group}


The assumption that a particular age group tends to behave and in a different way than other age groups. For instance, older owner/managers mostly appear to be at risk [17] and do not want to use bank loan. Younger owner/managers are perceived be innovative and good performers hence could attract credit accessibility. There are several studies that investigated the effect of age of applicant on access to credit, however there are mixed results, mainly on the significance of the variable. A study conducted by[17],[9] and [15] showed that age do not have significant effect on access to credit. [13] also found out that age and access to credit do not have significant relationship. However, contrary to the above findings, [17] demonstrated that age have significant effect on credit accessibility. [1] suggested that the positive of age group on access to credit prevails over the negative. Despite the mixed results it is hypothesised that age group will be a predictor of credit accessibility.

\subsubsection{Current position}

According to the report of [6] stated that the level of the position of the directors, manager, or the owner of the company will determine the loan or credit the organization can be secure, this is because credit seekers with higher position in the company and high management level can access loan or credit easily. Therefore it can be suggested that the current position of the applicant will predict credit accessibility.

\subsubsection{Types of business ownership}

[6], found that legal status influence the bank lending. [6] further stated that corporate status at start-up appears to be associated with a greater likelihood of bank lending. The existing empirical evidence supports the existence of a positive relationship between form of business ownership and credit leverage. For example, [12] found evidence supporting a positive relationship between credit leverage and sole trader on access to credit. Similarly, [17] and [13] suggest that sole traders are greater users of bank credit. Thus, the form of business ownership influences credit accessibility.

\subsubsection{Tax Number}

According to [14] pointed out that SMEs in the service sector reported a lower likelihood to register for tax than those in construction, agriculture, and manufacturing sectors. [8] indicated that SMEs employing workers were more likely to express a likelihood to register for tax than sole proprietors with no employees. Moreover, SMEs who kept complete financial records on paper and computer were more likely to report an intention to register for tax than those who did not keep such records. Furthermore, SMEs who agreed that Government gives a good return on taxes paid in the form of government services reported a much higher likelihood of tax registration. It can be suggested that when SMEs are offered incentives or the system is easy to work with they register for tax. However, it is suggested that tax registration is a path way to having a tax number, hence will aid in access to credit from the financial institutions.

\subsubsection{Location of the business}

The lenders who are geographically closer to their business owner are capable of utilising available qualitative information to establish the credibility of their customers for credit accessibility. [5] spotted that the location of the firm is dependent on access to the financial institution. According to [9] they indicated that the geographic nearness of the firm to the financial institution had an influence with the firm accessing credit. This is supported by [8] who affirmed that SMEs located in the towns are successful in accessing credit compared to those found in the countryside. These studies therefore propose that the location of the business predicts credit accessibility.

\subsubsection{Collateral security}

In lending agreements, collateral is a borrower's pledge of specific property to a lender, to secure repayment of a loan [10] and [5], [15]. The collateral serves as protection for a lender against a borrower's default - that is, any borrower failing to pay the principal and interest under the terms of a loan obligation. If a borrower does default on a loan (due to insolvency or other event), that borrower forfeits (gives up) the property pledged as collateral - and the lender then becomes the owner of the collateral. The study conducted by [2] and [3], established, that collateral is a major determinant of credit accessibility by SMEs.

\subsection{Operationalisation of the conceptual framework}

The model is made up of dependent variables which were dichotomous; credit accessibility defined by (I did access credit and did not access credit) and (I accessed full credit and I accessed partial credit ) and independent variables which are; gender, age group, current position, type of business ownership, business tax number, location of 
the company and collateral. The mathematical model 1 which is a general equation for logistic regression was used for this study to predict the independent variables influence on credit accessibility.

This can be written as:

$\ln (\mathrm{p} / 1-\mathrm{p})=\beta 0+\beta 1 \mathrm{x} 1+\beta 2 \mathrm{x} 2+\ldots+\beta \mathrm{kxk}$.

The specific logistic regression for the study was modelled as follows:

$\ln (\mathrm{p} / 1-\mathrm{p})=\beta 0+\beta 1$ Gender $+\beta 2$ Age Group $+\beta 3$ CurPostion $+\beta 4$ TypesBusOwnSh $+\beta 5$ TaxNo $+\beta 6$ LocBus + $\beta 7$ Collateral $\varepsilon$

\subsection{Research method and design}

The questionnaire included personal questions on age, gender, population group, education qualification, marital status, current position and years of experience in business. Other sections included company profile namely location of the business, ownership, construction industry development board (CIDB) [7] grading, number of full time employees. Requirements of financial institutions e.g. collateral and tax number. It is worth noting that not all these variables were included in two models for credit accessibility i.e. to predict full credit they applied for or any credit at all. The dependent variable for full credit was informed by, whether the SMEs received full credit or part of the credit. On the other hand the study also established whether the SMEs received the credit or did not receive credit. Statistical Package for Social Sciences (SPSS) version 22 was used to perform the binary logistic regression analysis on this dichotomous outcome.

A binary logistic regression model with dichotomous responses as dependent variables of Yes or No were modelled. Yes response was defined as having accessed full credit and No accessed part of the credit. The second dependent variable defined "Yes" as accessed credit and "No" did not access credit. For analysis to be conducted, the responses of the dependent variables were coded as 1 and 0 , for "Yes" and "No" respectively. The independent variables of the logistic regression model were coded. They conformed to the demographic and socio-economic characteristics of the SMEs: gender if male 1 and female 2; age group, 30 years and below 1, 31 years to 39 years 2, 40 years to 49 years 3 and 50 years and above 4; current position, director 1, owner 2, manager 3 and manager/owner 4; ownership, sole proprietorship 1, partnership 2, limited partnership 3, limited Liability company 4, corporation (forprofit) 5; tax number No, 0 and Yes, 1; location of business, city of Johannesburg Metropolitan Municipality 1, city of Tshwane Metropolitan Municipality 2, Ekurhuleni Metropolitan Municipality 4, West Rand District Municipality 4; collateral No, 0 and Yes, 1.

Logistic regression is recommended over linear regression when modeling dichotomous responses and allows the researcher to estimate probabilities of the response occurring (Hosmer and Lemeshow, 2004). The logistic regression equation takes the following form

$\ln (p / 1-p)=\beta 0+\beta 1 \times 1+\beta 2 \times 2+\ldots+\beta k x k$

Where $\mathrm{p}$ is the estimated probability of passing, and $\mathrm{x} 1, \mathrm{x} 2, \ldots, \mathrm{xk}$ are independent variables.

\subsection{Results and discussions}

Table 1 indicates that male respondents were the majority than female respondents, at $63 \%$ to $37 \%$ respectively. Majority i.e. 51\% of the respondents were in the age group between $40-49$ years old. $82 \%$ of the respondents occupied the position of owners. $98 \%$ of the SMEs are sole proprietors. Furthermore, majority i.e. $41 \%$ of the SMEs were located in the city of Johannesburg metropolitan. 
Table 1: Profile of respondents and organization

\begin{tabular}{|c|c|c|}
\hline Gender & Frequency & Percentage \\
\hline Male & 112 & $37 \%$ \\
\hline Female & 67 & Percentage \\
\hline Age group & Frequency & $27 \%$ \\
\hline 30 years and below & 2 & $51 \%$ \\
\hline $31-39$ years & 49 & $20 \%$ \\
\hline $40-49$ years & 92 & Percentage \\
\hline 50 years and above & 36 & $16 \%$ \\
\hline Current position & Frequency & $82 \%$ \\
\hline Director & 29 & $1 \%$ \\
\hline Owner & 146 & Percentage \\
\hline Manager & 3 & $98 \%$ \\
\hline Manager/owner & 1 & $1 \%$ \\
\hline Ownership & Frequency & $1 \%$ \\
\hline Sole proprietorship & 175 & $1 \%$ \\
\hline Partnership & 2 & Percentage \\
\hline Limited partnership & 1 & $41 \%$ \\
\hline Limited liability company (LLC) & 1 & $24 \%$ \\
\hline Location of company & 34 & $19 \%$ \\
\hline City of Johannesburg metropolitan & 29 & \\
\hline City of Tshwane metropolitan & Frequency & \\
\hline Ekurhuleni metropolitan & 74 & \\
\hline West Rand district municipality & & \\
\hline
\end{tabular}

The result in Table 2, $21.91 \%$ i.e. 39 of the respondents received part of the credit they applied for and $78.09 \%$ i.e. 139 of the respondents obtained the full credit. It can be indicated that some of the SMEs did not receive the full credit they applied from the financial institutions. The finding is in line with the theory of credit rationing, which was informed by [11]. This theory can be argued to be the demand of funds by small medium and micro enterprises (SMMEs) and the supply of funds [5]. Furthermore, one respondent did not indicate whether the company received full or partial credit. However, Table 5 justifies this finding as the respondent indicated the company did not receive credit at all.

Table 2: Full or partial credit accessed

\begin{tabular}{|l|l|l|}
\hline Credit accessed & Respondents & Percentage \\
\hline Accessed partial credit & 39 & $21.91 \%$ \\
\hline Accessed full credit & 139 & $78.09 \%$ \\
\hline Total & $\mathbf{1 7 8}$ & $\mathbf{1 0 0 . 0 0 \%}$ \\
\hline
\end{tabular}

The results in Table 3 indicates that of the seven demographic and socio-economic independent variables modelled to predict full credit accessibility. Age group 40-49 years were likely to receive full credit than applicants who were in the age group 30 years and below. This finding corroborates with the findings of [19] and [14] and [20]. It is interesting to note that applicants who are 30 years and young are have a likelihood of receiving partial credit than full credit. The current position predictor achieved a level of significance (p-value) of less than 0.050 . This reveals that the variable predicted full credit accessibility. The finding is in line with the findings of [6] and [11]. However, it is interesting to note that no category of the current position in the SMEs stated, predicted full credit accessibility. The level of significance ( $\mathrm{p}$-value) were greater than 0.05 for all categories of current position held in the organization.

Furthermore, the study found that when the SMEs provided their tax number they had a greater probability of accessing full credit, compared to those who do not provide there tax numbers. The level of significance was less than 0.05 at 0.015 hence a strong predictor. Furthermore, the SMEs whose premise were in Location, Ekurhuleni metropolitan municipality in Gauteng province had a higher probability of getting full credit, compared to SMEs in 
the city of Johannesburg metropolitan municipality. This predicator was significant at 0.043 which was less than 0.05 . The odds of getting the full credit was 0.247 more those in city of Johannesburg. This finding is supported by [4] and [9]. [6] and [20] indicated that the geographic nearness of the firm to the financial institution had an influence with the firm obtaining credit. On the other hand [9] indicated that those in urban areas were likely to obtain credit than those in rural areas. Therefore it can be suggested that the location of the business is vital for credit accessibility. The gender of the respondent, and type of ownership did not predict full credit accessibility. Furthermore, it is imperative to mention that collateral was not statistically interpreted in the output result of SPSS despite being included in the analysis as a predictor. However, prior to testing this model, the goodness of fit of the model was tested which indicated a good fit. This result was justified by the Hosmer and Lemeshow test. The significance of the model was greater than 0.05 at 0.271 . The result suggests that the independent variables were fitting in the proposed theoretical model.

Table 3: Predictors of accessing full credit

\begin{tabular}{|c|c|c|c|c|}
\hline Variable & Exp. (B) Odds ratio & $\begin{array}{lccc}95 \% & \text { C.I. } & \text { for } & \text { EXP } \\
\text { (B)Lower } & & \end{array}$ & $\begin{array}{l}\text { 95\% C.I. for EXP } \\
\text { (B) } \\
\text { Upper }\end{array}$ & P-value \\
\hline Gender (1) & 2.102 & 0.929 & 4.757 & 0.075 \\
\hline Age group & & & & 0.133 \\
\hline Age group 31-40 years (1) & 135383335.572 & 0.000 & . & 0.999 \\
\hline Age group $40-49$ years $(2)$ & 0.269 & 0.079 & 0.916 & 0.036 \\
\hline Age group 50 years and over (3) & 0.668 & 0.215 & 2.074 & 0.485 \\
\hline Current position & & & & 0.040 \\
\hline Current position owner (1) & 0.000 & 0.000 & . & 1.000 \\
\hline Current position manager (2) & 0.000 & 0.000 & . & 1.000 \\
\hline Current position manager/owner (3) & 2.191 & 0.000 & . & 1.000 \\
\hline Ownership & & & & 1.000 \\
\hline Ownership partnership (1) & 0.000 & 0.000 & . & 1.000 \\
\hline Ownership limited partnership (2) & 1.357 & 0.000 & . & 1.000 \\
\hline Ownership Limited Liability company (LLC) (3) & 1.274 & 0.000 & . & 1.000 \\
\hline Tax number (1) & 0.050 & 0.004 & 0.564 & 0.015 \\
\hline Location (municipality) & & & & 0.085 \\
\hline Location, City of Tshwane Metropolitan Municipality (1) & 0.785 & 0.218 & 2.828 & 0.711 \\
\hline Location, Ekurhuleni Metropolitan Municipality (2) & 0.246 & 0.063 & 0.958 & 0.043 \\
\hline \multirow[t]{2}{*}{ Location, West Rand District Municipality (3) } & 0.707 & 0.175 & 2.863 & 0.627 \\
\hline & $\begin{array}{l}34707472280467732 \\
00.000\end{array}$ & & & 0.999 \\
\hline
\end{tabular}

Dependent variable: full credit accessibility ( $0=$ partial credit; $1=$ full credit $)$ sig. at $5 \%$

Table 4 deduced that only $0.6 \%$ of the SMEs did not have access to credit while $99.4 \%$ of SMEs had obtained credit. Therefore, the majority of the respondents obtained credit. However this finding is contrary to the findings of [9] who found that in South Africa only $27 \%$ of SMEs obtained bank loans while $73 \%$ did not obtain the credit

Table 4: Accessibility of credit and no credit accessibility

\begin{tabular}{|l|c|c|}
\hline Access to credit & Frequency & Percentage \\
\hline No did not access credit & 1 & $0.6 \%$ \\
\hline Yes I did access credit & 178 & $99.4 \%$ \\
\hline Total & $\mathbf{1 7 9}$ & $\mathbf{1 0 0 . 0 0 \%}$ \\
\hline
\end{tabular}

The results in Table 5 indicates that of the seven independent variables modelled to predict credit accessibility were not significant hence the null hypothesis cannot be rejected. The results in Table 6 indicate that; gender, age group, current position, type of business ownership, location of business, tax number and collateral were not good predictors of credit accessibility. The results indicated the level of significance (p-value) of each predictor variable were greater than 0.05 . Furthermore, it is imperative to mention that collateral was not statistically interpreted in the output result 
of SPSS despite being included in the analysis as a predictor.

However, prior to testing this model, the goodness of fit of the model was tested which established a good fit. This was justified by the Hosmer and Lemeshow test. The significance of the model was greater than 0.05 at 0.988 . The result indicates that the independent variables were fitting in the proposed theoretical model and therefore further statistical analysis could be conducted.

Table 5: Binary logistic regression, predictors of accessing credit

\begin{tabular}{|c|c|c|c|c|}
\hline Variable & $\begin{array}{l}\text { Exp. (B) } \\
\text { Odds ratio }\end{array}$ & $\begin{array}{l}\text { 95\% C.I. for EXP (B) } \\
\text { Lower }\end{array}$ & $\begin{array}{l}\text { 95\% C.I. for EXP (B) } \\
\text { Upper }\end{array}$ & P-value \\
\hline Gender (1) & 1.547 & 0.812 & 2.947 & 0.184 \\
\hline Age group & & & & 0.376 \\
\hline $31-40$ years $(1)$ & 0.499 & 0.016 & 15.716 & 0.693 \\
\hline 40- 49 years (2) & 0.838 & 0.334 & 2.101 & 0.707 \\
\hline 50 years and over ( 3 ) & 1.557 & 0.695 & 3.486 & 0.282 \\
\hline Current position & & & & 0.526 \\
\hline Owner (1) & 1050190579.980 & 0.000 & . & 1.000 \\
\hline Manager (2) & 1665203759.364 & 0.000 & . & 1.000 \\
\hline Manager/owner (3) & 6315003273.235 & 0.000 &. & 1.000 \\
\hline Ownership & & & & 0.994 \\
\hline Partnership (1) & 0.000 & 0.000 & . & 1.000 \\
\hline Limited partnership (2) & 0.000 & 0.000 & . & 1.000 \\
\hline Limited Liability company (LLC) (3) & 1.733 & 0.000 & . & 1.000 \\
\hline Tax number (1) & 0.324 & 0.045 & 2.353 & 0.265 \\
\hline Location (municipality) & & & & 0.587 \\
\hline $\begin{array}{l}\text { City of Tshwane Metropolitan } \\
\text { Municipality (1) }\end{array}$ & 0.577 & 0.222 & 1.498 & 0.259 \\
\hline $\begin{array}{l}\text { Ekurhuleni Metropolitan Municipality } \\
\text { (2) }\end{array}$ & 0.520 & 0.178 & 1.521 & 0.232 \\
\hline \multirow[t]{2}{*}{ West Rand District Municipality (3) } & 0.499 & 0.169 & 1.470 & 0.207 \\
\hline & 3470747228046773200.000 & & & \\
\hline
\end{tabular}

\section{Conclusions}

The study elicited information from SMEs personnel who are conversant with the credit accessibility within their enterprise. The study found that SMEs are stifled from accessing credit because of lack of collateral/security, lack of cash flow statement and owners' equity. However, despite the constraints of accessing credit which could be a stumbling block to credit accessibility, the results suggest that majority of SMEs received credit whether full credit or partial credit. However, despite the SMEs obtaining partial credit it can hinder their progress. It can be suggested that when construction SMEs receive part of the credit they might apply for credit in other financial institutions or request financial assistance from friends in order to cover for the deficit.

The researchers established that for SMEs to access full credit from the financial institutions age group, current position in the organization of the respondent applying for credit predicated full accessibility. Furthermore, tax number and location of the business in the Gauteng province were also predicators of full credit accessibility. However, the gender of the respondent, type of business ownership and collateral (security) did not predict full credit accessibility by SMEs. However when the predicators were modelled with whether the SMEs received credit or did not receive credit the predicators were not good determinants.

\section{Recommendations of the study}


Based on the conclusions, the study recommends the findings to different stakeholders, that is:

\section{Recommendations to government}

The government needs to encourage construction SMEs to approach commercial financial institutions to apply for credit as majority of SMEs obtained credit from them. The notion that commercial financial institutions reject or deny SMEs credit should be argued with caution as this study indicates that majority of SMEs acquired their credit from commercial financial institutions.

The government needs to inform financial institutions not to be too stringent with collateral (security), owners' equity and cash flow statement as these are the constraints impeding SMEs from credit accessibility.

\section{Recommendation to financial institutions}

The financial institutions should be aware of this constraints construction SMEs encounter in accessing credit. Collateral (security), owners' equity and cash flow statement should not be mandatory requirements in order for SMEs to acquire credit. Other requirements should be suggested which will make it easy for SMEs to access credit.

\section{Recommendation to construction SMEs}

SMEs should be informed that they should provide the age, and current position in the organization of the person applying for the credit. Furthermore, they should provide the tax number and the location of the business in order for them to obtain full credit they apply for. However, it is worth indicating that SMEs should also be aware of the requirements that the financial institutions will request them to submit as they apply for credit.

\section{Limitation(s) of the study}

The study cannot be generalised across South Africa because the study was only conducted in the Gauteng province.

\section{Further study}

- Firstly, further research could determine if the findings of this research are consistent across different sectors. Since the study concentrated on SMEs in the construction sector only. A further research in other sectors will shed more light on the findings of this study;

- In addition, there is the need to replicate this research in other parts of South Africa to confirm if the results of this research can be generalized across the country;

- This study can also be carried out in other African countries for comparative purposes;

- Though the study establishes some predictors on access to full credit, not all the variables were good predicators. Therefore, a further study can be undertaken to justify this findings;

- The study proposes the use of stepwise logistic regression in future study; and

- A further research to test other independent variables not included in this study will be critical. The factors recommended for testing are marital status of the applicant, bank account statement and managerial ability of the respondents

\section{References}

[1] Aduda, J., Magutu, O.P. and Wangu, G.M., 2012, The Relationship between Credit Scoring Practices by Commercial Banks and Access to Credit by Small and Medium Enterprises in Kenya, International Journal of Humanities and Social Science, 2, 9, 203-213.

[2] Agumba, N. J. (2013). A construction health and safety performance improvement model for South African small and medium enterprises. Unpublished doctoral Thesis, Faculty of Engineering and the Built Environment, University of Johannesburg, South Africa.

[3] Agumba, J.N., Adegoke, I.O. and Otieno, F.A.O., 2005, Evaluating Project Management Techniques in Small and Medium Enterprises Delivering Infrastructure in South Africa Construction Industry. Proceedings of 3rd Postgraduate Conference 2005, Construction Industry Development, Eskom Convention Center, Midrand, Johannesburg, South Africa, $9^{\text {th }}-11^{\text {th }}$ October, $52-65$

[4] Alhassan, F. and Sakara, A., 2014, Socio-Economic Determinants of Small and Medium Enterprises' (Smes) Access to Credit from the Barclays Bank in Tamale-Ghana, International Journal of Humanities \& Social Science Studies, I, II, 26-36

[5] Angela and Motsa Associates, 2004, SMME Finance Sector Background Paper: A Review of key documents on SMME Finance 1994-2004. Fin Mark Trust: Johannesburg. 
[6] Bondinuba, F.W., 2012, Exploring the Challenges and Barriers in Accessing Financial Facilities by Small and Medium Construction Firms in Ghana, Civil and Environmental Research, 2, 6, 25-35.

[7] Construction Industry Development Board, 2008, Construction Health and Safety in South Africa, Status and Recommendations. Pretoria, South Africa.

[8] Department of Public Works, 1999, White paper on Creating an Enabling Environment for Reconstruction Growth and Development in the Construction Industry, Government Printers, Republic of South Africa. http://www.info.gov.za/whitepaper/1999/environment.htm last accessed on the 01/02/2015.

[9] Fatoki, O., 2014, Factors Influencing the Financing of Business Start-ups by Commercial Banks in South Africa, Mediterranean Journal of Social Sciences, 5, 20, 94-100.

[10] Fin-Mark Trust. (2006). Fin scope small business survey report. [Online] Available:

http://www.finmarktrust.org.za (May 18, 2007).

[11] Foxcroft, M., E. Wood, J. Kew, M. Herrington and N. Segal, (2002), Global Entrepreneurship Monitor: South African Executive Report, Graduate School of Business: University of Cape Town.

[12] Grimsholm, E., and Poblete, L., 2011, Internal and External factors hampering SME growth-A qualitative case study of SMEs in Thailandunpublished masters thesis, Gotland University.

[13] Kayanula, D. \& Quartey, P., 2000, The Policy Environment for Promoting Small and Medium-Sized Enterprises in Ghana and Malawi, Finance and Development Research Programme, Working Paper Series, Paper No 15, IDPM, University of Manchester.

[14] Mandell, L., 1994, The Credit Card Industry: A History, Boston, Twayne Publishers.

[15] Martin, 1. 2010, Challenges faced by South African emerging contractors- review and update. Proceedings of the Construction, Building and Real Estate Research conference of Royal Institute of Chartered Surveyors, Dauphine Universite, Paris $2^{\text {nd }}-3^{\text {rd }}$ September, France.

[16] National Small Business Act. 2004, Number 29 of 2004 Republic of South Africa. Available from: http://www.info.gov.za/view/DownloadFileAction?id=67967 last accessed 18/04/2016.

[17] Nkuah, K.J., Tanyeh, P.J., and Gaeten, K., 2013, Financing small and medium enterprises (SMEs) in Ghana: Challenges and determinants in accessing bank credit, International Journal of Research in Social Sciences, 2, 3, 12-25.

[18] Ntsika Enterprise Promotion Agency. (2002). State of small business development in South Africa annual review. [Online] Available: http://www.ntsika.org.za/ (April 19, 2007).

[19] Organization for Economic Cooperation and Development (OECD, 2006), The SMEs Financing Gap Volume 1: Theory and Evidence. Retrieved from: http://ec.europa.eu/enterprise/newsroom/cf/document.cfm?action=display\&doc-id=624\&userservice last accessed on the $11 / 03 / 2016$

[20] Pallant, J. 2013, SPSS, Survival Manual: A step-by-step guide to data analysis using IBM, SPSS, 5th Edition, Allen \& Unwin, Sydney, Melbourne, Auckland, London. 